\title{
PENGARUH LEVEL ENERGI DALAM PAKAN TERHADAP KUALITAS SPERMATOZOA AYAM KAMPUNG SECARA MIKROSKOPIS
}

\author{
Effect of Energy Level in Feed on Microscopic Quality of Native Chicken Spermatozoa \\ Nining Haryuni ${ }^{1}$, Anna Lidyawati ${ }^{1}$, Binti Khopsoh ${ }^{1}$ dan Niswatin Hasanah' ${ }^{2}$ \\ 1Jurusan Peternakan, Universitas Nahdlatul Ulama Blitar \\ 2Jurusan Peternakan, Politeknik Negeri Jember \\ Email: niningharyuni@gmail.com
}

\begin{abstract}
INTISARI
Tujuan dari penelitian ini adalah mengetahui pengaruh level energi dalam pakan terhadap kualitas spermatozoa. Materi yang digunakan dalam penelitian ini adalah ayam kampung pejantan umur 80 minggu, pakan perlakuan, natrium clorida 3\%, eosin dan aquades. Penelitian ini menggunakan Rancangan Acak Lengkap (RAL) yang terdiri dari 4 perlakuan, masing-masing perlakuan diulang sebanyak 4 kali. Setiap ulangan terdiri dari 1 ekor ayam kampung pejantan. Koleksi semen dengan menggunakan metode pemijatan pada daerah abdominal. Hasil dari penelitian menunjukkan bahwa level energi dalam pakan memberikan pengaruh yang sangat nyata $(\mathrm{P}<0,01)$ meningkatkan gerak massa spermatozoa dan menurunkan motilitas spermatozoa. Rata-rata skor gerak massa spermatozoa yang didapatkan pada penelitian ini berkisar antara $1,50 \pm 0,58 \%$ sampai $3,00 \pm 0,00 \%$, motilitas spermatozoa berkisar antara $68,75 \pm 2,50 \%$ sampai $80,0 \pm 0,00 \%$. Level energi dalam pakan memberikan pengaruh yang nyata $(\mathrm{P}<0,05)$ pada peningkatan konsentrasi spermatozoa dan jumlah spermatozoa hidup. Rata- rata konsentrasi spermatozoa yang didapatkan pada penelitian ini berkisar antara $2,75 \times 10^{9} \pm 0,50$ $\mathrm{sel} / \mathrm{ml}$ sampai $3,75 \times 10^{9} \pm 0,19 \mathrm{sel} / \mathrm{ml}$ dan jumlah spermatozoa hidup berkisar antara $89,50 \pm 1,732 \%$ sampai $92,50 \pm 1,29 \%$. Level energi dalam pakan memberikan pengaruh yang tidak nyata $(\mathrm{P}>0,05)$ terhadap abnormalitas spermatozoa. Rata-rata persentase abnormalitas spermatozoa yang didapatkan pada penelitian ini berkisar antara $2,27 \pm 0,19 \%$ sampai $2,38 \pm 0,10 \%$. Berdasarkan hasil penelitian dapat disimpulkan bahwa level energi dalam pakan dapat memperbaiki kualitas spermatozoa.
\end{abstract}

Kata kunci: Ayam Kampung, Kualitas Spermatozoa, Level Energi, Pakan

\begin{abstract}
The purpose of this study was to determine the effect of energy levels in feed on the quality of spermatozoa. The materials used in this study were 80 weeks old male native chickens, rations, $3 \%$ sodium chloride, eosin, and distilled water. This study used a Completely Randomized Design (CRD) consistied of 4 treatments and each treatment was repeated 4 times. Each repeatation was a male native chicken. Collection of semen used the massage method on the abdominal area. The results of the study showed that the energy level in the rations increased $(P<0.01)$ the mass motion and decreased the motility of spermatozoa. The mean of mass motion scores obtained ranged $1.50 \%$ to $3.00 \%$, and the motility ranged $68.75 \%$ to $80.0 \%$. The energy level in the rations increased $(P<0.05)$ on the concentration and the number of live spermatozoa. The mean of concentration obtained ranged $2.75 \times 10^{9} \mathrm{cells} / \mathrm{ml}$ to $3.75 \times 10^{9} \mathrm{cells} / \mathrm{ml}$ and the number of live spermatozoa ranged from $89.50 \%$ to $92.50 \%$. Energy level in rations had no significant effect $(P>0.05)$ on spermatozoa abnormality. The mean percentage of abnormal spermatozoa obtained ranged $2.27 \%$ to $2.38 \%$. Based on this result, it can be concluded that the energy level in the rations could improve the quality of spermatozoa.
\end{abstract}

Keywords: Native Chickens, Spermatozoa Quality, Energy Level, Feed 


\section{PENDAHULUAN}

Ayam kampung merupakan unggas lokal asli Indonesia yang dikembangkan dalam upaya memenuhi kebutuhan daging dan telur yang diharapkan dapat mendukung kemandirian penyediaan pangan nasional sesuai dengan Peraturan Pemerintah Nomor 68 Tahun 2002 tentang Ketahanan Pangan dengan Menekankan Kemandirian Penyediaan Pangan Berbasis Sumber Daya Lokal.

Peningkatan jumlah penduduk yang diiringi dengan kesadaran akan pentingnya nilai gizi menyebabkan kebutuhan pangan khususnya asal hewani mengalami peningkatan. Berdasarkan data yang diperoleh dari Pusat Data dan Informasi Pertanian Kementrian Pertanian (2016) tingkat konsumsi daging ayam kampung pada tahun 2015 mengalami peningkatan sebesar 25,40\% dari $0,499 \mathrm{~kg} / \mathrm{kapita} /$ tahun pada tahun 2014 menjadi $0,63 \mathrm{~kg} / \mathrm{kapita} / \mathrm{tahun}$ pada tahun 2015.

Perkembangan populasi ayam kampung di Indonesia pada tahun 2012-2016 secara nasional mengalami stagnasi namun cenderung meningkat dengan pertumbuhan rata-rata sebesar 2,49\% per tahun atau ratarata populasi ayam kampung per tahun sebesar 282,09 juta ekor. Peningkatan konsumsi ayam kampung disebabkan karena cita rasa dari daging ayam kampung lebih disukai oleh konsumen dari pada daging ayam ras (Iskandar, 2012).

Sistem pemeliharaan ayam kampung di Indonesia dilakukan dengan 3 macam sistem pemeliharaan yaitu secara tradisional, semi intensif, dan intensif. Sekitar $80 \%$ pemeliharaan ayam kampung dilakukan secara tradisional di pedesaan dengan populasi kurang dari 30 ekor pada setiap peternak (Iskandar, 2012). Pengembangan ayam kampung secara nasional masih tergolong rendah karena pada umumnya masih dimanfaatkan sebagai tambahan pendapatan. Rendahnya pengembangan usaha ayam kampung menurut Nataamijaya (2010) disebabkan karena belum tersedianya bibit unggul dan pemeliharaan yang kurang efisien. Managemen pemeliharaan ayam kampung di daerah Batu Jawa Timur dilakukan dengan sistem yang sederhana (Suyatno, 2003).

Penanganan reproduksi ternak masih dilakukan dengan menerapkan kawin alami yang secara ekonomis kurang efisien sebab membutuhkan pejantan dalam jumlah yang banyak. Disamping itu penetasan masih dilakukan dengan menggunakan mesin tetas yang masih sederhana sehingga daya tetas yang dihasilkan juga tergolong masih rendah yaitu berkisar $62 \%$.

Kendala yang dihadapi dalam usaha komersial ayam kampung yang dipelihara secara intensif adalah kurangnya pengadaan ayam dara untuk menggantikan induk produktif (Utami, 2009). Penggantian induk produktif masih didapatkan dari ayam dara hasil tetas dengan indukan sistem umbaran dan juga didapatkan dari pasokan pedagang ayam lokal. Salah satu cara yang dapat digunakan untuk meningkatkan produktivitas ayam kampung adalah menggunakan teknologi reproduksi dengan cara inseminasi buatan (IB)(Sutiyono et al., 2006).

Teknologi IB dapat digunakan untuk memperbaiki mutu genetik ayam dengan melakukan persilangan pada ayam unggul misalnya ayam ras petelur. Teknologi IB dapat digunakan sebagai salah satu terobosan untuk meningkatkan produktivitas ayam kampung. Keberhasilan kegiatan IB pada ayam sangat dipengaruhi oleh beberapa faktor antara lain: strain ayam, umur, pengencer yang digunakan, derajat pengenceran atau dosis inseminasi, kualitas semen, deposisi semen, dan waktu inseminasi (Danang et al., 2012).

Bentuk spermatozoa ternak unggas adalah filiformis. Penyusun kepala spermatozoa ayam adalah nukleus yang bagian atasnya tertutup oleh akrosom yang berbentuk kerucut dan sedikit melengkung. Ekor spermatozoa terdiri dari bagian leher, bagian tengah, bagian utama dan bagian ujung (Johari et al., 2009). Kepala spermatozoa ayam 
memiliki panjang sekitar $12,77 \mu \mathrm{m}$. Kepala spermatozoa ayam terdiri dari akrosom dan nukleus yang masing-masing mempunyai panjang 1,91 $\mu \mathrm{m}$ dan 10,85 $\mu \mathrm{m}$. Akrosom memiliki peran yang sangat penting dalam proses fertilisasi karena adanya enzim yang berperan dalam proses fertilisasi yaitu proakrosin, hialuronidase, zoana lisin esterase dan asam hidrolase.

Bagian tengah spermatozoa memiliki panjang 4,22 $\mu \mathrm{m}$ sedangkan bagian ekor mempunyai panjang $75,74 \mu \mathrm{m}$. Bagian tengah spermatozoa berfungsi sebagai pemasok energi dengan adanya produksi ATP di dalam mitokondria. Semakin panjang bagian tengah spermatozoa maka pasokan energi juga semakin besar. Bagian ekor spermatozoa berfungsi sebagai alat gerak spermatozoa (Ardhani et al., 2018). Semakin banyak energi yang dihasilkan oleh bagian tengah spermatozoa akan berdampak pada aktifitas gerak yang semakin tinggi pula. Oleh sebab itu, perlu adanya penelitian penambahan level energi pada pakan untuk meningkatkan kualitas spermatozoa pada ayam kampung.

\section{MATERI DAN METODE}

Bahan yang digunakan dalam penelitian ini adalah ayam pejantan kampung umur 80 minggu, pakan perlakuan dengan tingkat energi yang berbeda, semen hasil pakan perlakuan, Natrium klorida 3\%, pewarna Eosin sitrat, aquades.

Metode penelitian yang digunakan pada penelitian ini adalah metode penelitian lapang dan laboratorium. Penelitian ini menggunakan Rancangan Acak Lengkap dengan 4 perlakuan dan 4 ulangan dan masing-masing perlakuan terdiri dari 1 ekor ayam. Penampungan semen dilakukan dengan menggunakan metode pijat urut pada daerah abdomen sampai kloaka hingga pejantan merasa terangsang yang ditandai dengan terangkatnya bulu pada pada daerah ekor. Pemijatan dilakukan dengan menggunakan tekanan tertentu hingga keluar cairan yang berwarna putih. Selanjutnya semen di tampung dalam tabung berskala untuk mengetahui berapa volumenya.

Campuran pakan dan kandungan nutrisi pakan perlakuan yang digunakan dalam penelitian ini dapat dilihat pada Tabel 1 dan Tabel 2. Perlakuan pada penelitian ini adalah sebagai berikut:

P0: Pakan Perlakuan dengan Energi Metabolis $2700 \mathrm{Kcal} / \mathrm{kg}$

P1: Pakan Perlakuan dengan Energi Metabolis $2750 \mathrm{Kcal} / \mathrm{kg}$

P2: Pakan Perlakuan dengan Energi Metabolis $2800 \mathrm{Kcal} / \mathrm{kg}$

P3: Pakan Perlakuan dengan Energi Metabolis $2850 \mathrm{Kcal} / \mathrm{kg}$

Tabel 1. Campuran Pakan Perlakuan

\begin{tabular}{lccccc}
\hline \multirow{2}{*}{ Bahan Baku } & Harga Bahan Baku & \multicolumn{4}{c}{ Perlakuan } \\
\cline { 3 - 6 } & per kg (Rp) & P0 & P1 & P2 & P3 \\
\hline Jagung lokal (\%) & 4.000 & 48,23 & 52,33 & 53,13 & 50,33 \\
BKK Argentina (\%) & 6.150 & 21,80 & 22,20 & 22,10 & 22,40 \\
MBM (\%) & 7.700 & 12,90 & 8,20 & 8,00 & 8,00 \\
Bekatul (\%) & 3.000 & 8,00 & 8,00 & 6,80 & 7,90 \\
Grit Batu (\%) & 300 & 5,00 & 5,00 & 5,00 & 5,00 \\
Tepung Batu (\%) & 300 & 3,10 & 3,10 & 3,10 & 3,10 \\
Minyak (\%) & 10.000 & 0,00 & 0,20 & 0,90 & 2,30 \\
Premik (\%) & 85.000 & 0,50 & 0,50 & 0,50 & 0,50 \\
DCP (\%) & 10.000 & 0,30 & 0,30 & 0,30 & 0,30 \\
Garam (\%) & 1.400 & 0,10 & 0,10 & 0,10 & 0,10 \\
Sodium Bicarbonat (\%) & 5.500 & 0,07 & 0,07 & 0,07 & 0,07 \\
\hline Harga Pakan Perlakuan per kg (Rp) & 4.757 & 4.825 & 4.879 & 4.958 \\
\hline
\end{tabular}

Keterangan: Perhitungan dengan menggunakan software Brill Formulation 
Tabel 2. Kandungan Nutrisi Pakan Perlakuan

\begin{tabular}{lcccc}
\hline \multirow{2}{*}{ Kandungan Nutrisi } & \multicolumn{4}{c}{ Perlakuan } \\
\cline { 2 - 5 } & P0 & P1 & P2 & P3 \\
\hline Energi Metabolis (Kcal/kg) & 2698,60 & 2751,40 & 2799,80 & 2851,60 \\
Protein Kasar (\%) & 19,15 & 19,12 & 19,00 & 19,01 \\
Lemak Kasar (\%) & 4,47 & 4,23 & 4,78 & 6,20 \\
Serat Kasar (\%) & 3,66 & 3,25 & 3,11 & 3,17 \\
Kalsium (\%) & 3,91 & 3,91 & 3,91 & 3,91 \\
Phospor Total (\%) & 0,84 & 0,78 & 0,76 & 0,77 \\
Phospor Avail (\%) & 0,51 & 0,49 & 0,49 & 0,49 \\
Sodium (\%) & 0,13 & 0,13 & 0,13 & 0,13 \\
Chloride (\%) & 0,15 & 0,15 & 0,15 & 0,15 \\
Abu (\%) & 3,63 & 3,65 & 3,65 & 3,67 \\
\hline
\end{tabular}

Keterangan: Perhitungan dengan menggunakan software Brill Formulation

\section{Variabel yang Diamati}

\section{Konsentrasi spermatozoa}

Konsentrasi spermatozoa adalah jumlah sel spermatozoa yang ada pada semen. Perhitungan jumlah konsentrasi spermatozoa dapat dilakukan dengan menggunakan haemocytometer.

\section{Gerak massa spermatozoa}

Gerakan massa spermatozoa merupakan petunjuk derajat keaktifan pergerakan sperma yang dapat digunakan sebagai salah satu indikator tingkat sperma yang hidup dan aktif dalam semen.

\section{Motilitas spermatozoa}

Motilitas spermatozoa adalah kemampuan spermatozoa untuk bergerak secara progresif menuju ovum dalam menentukan pembuahan.

\section{Spermatozoa hidup}

Spermatozoa hidup adalah banyak spermatozoa yang hidup dalam semen. Pengamatan jumlah spermatozoa hidup dapat dilakukan dengan menggunakan mikroskop cahaya dengan pembesaran 400 kali.

\section{Abnormalitas spermatozoa}

Anormalitas spermatozoa adalah ketidaknormalan bentuk dari spermatozoa. Pada umumnya abnormalitas spermatozoa dapat diamati dari segi bentuk (bentuk dan ukuran kepala, serta bentuk dan ukuran ekor). Ketidaknormalan spermatozoa penting digunakan untuk mengetahui tingkat fertilitas.

Tabel 3. Deskripsi Skor Penilaian Evaluasi Semen Secara Makroskopis dan Mikroskopis

\begin{tabular}{cccc}
\hline \multirow{2}{*}{ Skor } & \multicolumn{3}{c}{ Evaluasi semen secara makroskopis dan mikroskopis } \\
\cline { 2 - 4 } & Warna & Konsistensi & Gerakan massa \\
\hline 1 & Krem & Cair & + \\
2 & Putih susu & Sedang & ++ \\
3 & Putih keruh & Kental & +++ \\
\hline
\end{tabular}

(Ariyanti et al., 2017)

\section{PEMBAHASAN}

Pengaruh level energi dalam pakan terhadap kualitas spermatozoa ayam kampung pejantan secara mikroskopis.. Ratarata kualitas spermatozoa ayam kampung pejantan yang diberi perlakuan level energi dalam pakan disajikan pada Tabel 4

\section{Konsentrasi Spermatozoa}

Analisis statistik menunjukkan bahwa level energi dalam pakan memberikan pengaruh yang nyata $(\mathrm{P}<0,05)$ meningkatkan konsentrasi spermatozoa. Rata-rata konsentrasi spermatozoa pada penelitian ini berkisar antara $2,75 \times 10^{9} \mathrm{sel} / \mathrm{ml}$ sampai $3,34 \times 10^{9} \mathrm{sel} / \mathrm{ml}$. Rata-rata konsentrasi 
spematozoa yang paling tinggi didapatkan pada perlakuan P3 yaitu sebesar 3,34\%. Ratarata konsentrasi spermatozoa pakan perlakuan dengan meningkatkan energi dalam pakan yang didapatkan pada penelitian ini tidak jauh berbeda dengan hasil penelitian Danang et al., (2012) yaitu sebesar $3,13 \times 10^{9}$ dan hasil penelitian Saleh dan Sugiyatno (2007) yang melakukan pada ayam kampung umur sekitar 48-70 minggu yaitu sebesar $3,51 \times 10^{9}$. Hal ini menunjukkan bahwa peningkatan level energi pada pakan dapat memperbaiki kualitas spermatozoa pada ayam kampung pejantan umur 80 minggu.

Tabel 4. Rata-Rata Kualitas Spermatozoa Ayam Kampung Pejantan Yang Diberi Perlakuan Level Energi Dalam Pakan

\begin{tabular}{cccccc}
\hline \multirow{2}{*}{ Perlakuan } & \multicolumn{5}{c}{ Variabel } \\
\cline { 2 - 6 } & $\begin{array}{c}\text { Konsentrasi } \\
\text { spermatozoa } \\
\left(10^{9}\right) / \mathrm{ml}^{* *}\end{array}$ & $\begin{array}{c}\text { Gerak massa } \\
\text { spermatozoa* }^{*}\end{array}$ & $\begin{array}{c}\text { Motilitas } \\
\text { spermatozoa } \\
(\%)^{*}\end{array}$ & $\begin{array}{c}\text { Spermatozoa } \\
\text { hidup (\%)** }\end{array}$ & $\begin{array}{c}\text { Abnormalitas } \\
\text { spermatozoa } \\
(\%)^{* *}\end{array}$ \\
\hline P0 & $2,75 \pm 0,50^{\mathrm{a}}$ & $1,50 \pm 0.58^{\mathrm{a}}$ & $68,75 \pm 2,50^{\mathrm{a}}$ & $89,50 \pm 1,73^{\mathrm{a}}$ & $2,38 \pm 0,10$ \\
P1 & $3,30 \pm 0,22^{\mathrm{b}}$ & $2,25 \pm 0,50^{\mathrm{a}}$ & $80,00 \pm 0,00^{\mathrm{b}}$ & $91,00 \pm 0,82^{\mathrm{a}}$ & $2,28 \pm 0,26$ \\
P2 & $3,33 \pm 0,10^{\mathrm{b}}$ & $3,00 \pm 0,00^{\mathrm{b}}$ & $80,00 \pm 0,00^{\mathrm{b}}$ & $92,25 \pm 0,50^{\mathrm{ab}}$ & $2,30 \pm 0,14$ \\
P3 & $3,34 \pm 0,19^{\mathrm{b}}$ & $3,00 \pm 0,00^{\mathrm{b}}$ & $80,00 \pm 0,00^{\mathrm{b}}$ & $92,50 \pm 1,29^{\mathrm{b}}$ & $2,28 \pm 0,19$ \\
\hline
\end{tabular}

Keterangan: * Notasi yang berbeda pada kolom yang sama memberikan pengaruh yang sangat nyata $(\mathrm{P}<0,01)$ terhadap gerak massa spermatozoa dan motilitas spermatozoa

** Notasi yang berbeda pada kolom yang sama memberikan pengaruh yang nyata $(\mathrm{P}<0,05)$ terhadap konsentrasi spermatozoa dan jumlah spermatozoa hidup, serta abnormalitas spermatozoa

Peningkatan level energi dapat meningkatkan konsentrasi spermatozoa disebabkan energi mempunyai peran yang sangat penting dalam proses metabolisme sel. Energi berfungsi sebagai bahan bakar dalam proses metabolisme. Menurut Zahri et al., (2018) energi mempunyai peran yang penting dalam metabolisme sel otak dan perkembangan gonad. Menurut Arief (2018) otak mempunyai bagian yang disebut hipotalamus yang berfungsi untuk menghasilkan hormon gonadotropin. Hormon gonadotropin merupakan hormon yang mengendalikan proses spermatogenesis. Meningkatnya kadar hormon gonadotropin pada proses spermatogenesis akan meningkatkan jumlah spermatozoa yang dihasilkan.

\section{Gerak Massa Spermatozoa}

Analisis statistik menunjukkan bahwa level energi dalam pakan memberikan pengaruh yang sangat nyata $(\mathrm{P}<0,01)$ meningkatkan gerak massa spermatozoa. Rata-rata skor gerak massa spermatozoa yang didapatkan pada penelitian ini berkisar antara 1,50-3,00. Skor rata-rata gerak massa spermatozoa tertinggi didapatkan pada P2 dan P3 yaitu sebesar 3,00.

Jumlah energi yang dikonsumsi oleh ayam akan berdampak pada gerak massa spermatozoa (Ariyanti et al., 2017). Energi hasil metabolisme yang dimanfaatkan untuk daya gerak spermatozoa adalah energi dalam bentuk ATP (Danang et al., 2017). Semakin tinggi energi yang dihasilkan maka gerak massa spermatozoa juga akan semakin tinggi, begitu sebaliknya semakin rendah kandungan energi maka gerak massa spermatozoa juga akan semakin menurun.

\section{Motilitas Spermatozoa}

Analisis statistik menunjukkan bahwa level energi dalam pakan memberikan pengaruh yang sangat nyata $(\mathrm{P}<0,01)$ meningkatkan motilitas. Rata-rata motilitas spermatozoa terendah didapatkan pada perlakuan P0 yaitu sebesar 68,75\% dan untuk perlakuan P1, P2 dan P3 persentase rata-rata motilitas spermatozoa adalah sama yitu 
sebesar 80\%. Motilitas spermatozoa merupakan salah satu parameter yang dapat digunakan untuk menentukan kualitas spermatozoa dan kemampuan spermatozoa dalam membuahi ovum pada saat proses fertilisasi (Danang et al., 2012). Rata-rata motilitas spermatozoa yang didapatkan pada penelitian ini tidak jauh beda dengan penelitian Saleh dan Sugiyatno (2007) yaitu sebesar 77,14\% dan penelitian yang dilakukan oleh Danang et al. (2012) yaitu sebesar $77,50 \%$. Membran plasma sel tersusun dari makromolekul yang berupa protein, lipoprotein, dan glikoprotein.

Kandungan energi dalam pakan yang tinggi dapat meningkatkan kualitas membran plasma spermatozoa. Metabolisme sel akan berjalan dengan baik apabila kondisi membran plasma dalam kodisi utuh sehingga laju lalu lintas keluar masuknya sel semua substrat dan elektrolit yang dibutuhkan untuk proses metabolisme akan berjalan dengan baik. Hasil dari metabolisme adalah energi dalam bentuk ATP (Danang et al., 2012).

Menurut Saleh dan Isyanto (2011) energi dalam bentuk ATP yang dihasilkan dari proses metabolisme akan digunakan untuk aktivitas gerak spermatozoa. Semakin tinggi energi yang dihasilkan maka aktivitas gerak spermatozoa juga akan semakin tinggi. Hal senada juga diungkapkan oleh Saleh dan Sugiyanto (2007) yang menyebutkan bahwa kurangnya pasokan energi dapat menyebabkan terjadinya penurunan motilitas spermatozoa.

\section{Spermatozoa Hidup}

Analisis statistik menunjukkan bahwa level energi dalam pakan memberikan pengaruh yang nyata $(\mathrm{P}<0,05)$ meningkatkan jumlah spermatozoa hidup. Rata-rata jumlah spermatozoa hidup yang didapatkan pada penelitian ini berkisar antara 89,50\%-92,50\%. Rata-rata jumlah spematozoa hidup yang paling tinggi didapatkan pada perlakuan P3 yaitu sebesar 92,50\%. Rata-rata spermatozoa hidup yang didapatkan pada penelitian ini hampir sama dengan penelitian Danang et al.
(2012) yaitu sebesar 92,60\% dan lebih tinggi jika dibandingkan penelitian Saleh dan Sugiyatno (2007) yaitu sebesar 86\%.

Membran plasma sel spermatozoa tersusun dari glikolipida dan glikoprotein yang disebut selubung glikokaliks. Glikokaliks berfungsi untuk melindungi membran plasma dari kerusakan (Danang et al., 2012). Penambahan level energi dalam pakan dapat meningkatkan kualitas membran plasma spermatozoa. Kondisi membran plasma yang baik akan berdampak pada kemampuan spermatozoa untuk dapat bertahan hidup. Semakin baik kondisi membran plasma maka semakin banyak jumlah spermatozoa yang hidup.

\section{Abnormalitas Spermatozoa}

Analisis statistik menunjukkan bahwa level energi dalam pakan memberikan pengaruh yang tidak nyata $(\mathrm{P}>0,05)$ terhadap abnormalitas spermatozoa. Rata-rata persentase abnormalitas spermatozoa yang didapatkan pada penelitian ini berkisar antara 2,28\%-2,38\%. Persentase rata-rata abnormalitas spermatozoa yang paling tinggi didapatkan pada P0 yaitu sebesar 2,38\%. Rata-rata abnormalitas spermatozoa yang didapatkan pada penelitian ini lebih rendah jika dibandingkan dengan penelitian Saleh dan Sugiyatno (2007) yaitu sebesar $8,50 \%$.

Hasil rata-rata persentase abnormalitas spermatozoa yang didapatkan pada penelitian ini juga lebih rendah jika dibandingkan dengan penelitian Danang et al., (2012) yaitu sebesar 5,10\%. Menurut Ardhani et al., (2018) faktor yang berpengaruh terhadap abnormalitas spermatozoa diantaranya adalah penyakit, stres panas, proses kriopreservasi, strain ayam, musim dan preservasi pasca koleksi dan pewarnaan pada saat analisis.

\section{KESIMPULAN}

Kesimpulan dari penelitian ini adalah penambahan level energi dalam pakan dapat meningkatkan konsentrasi spermatozoa, gerak massa spermatozoa, motilitas spermatozoa dan jumlah spermatozoa hidup. 
Penambahan level energi dalam pakan memberikan pengaruh yang tidak nyata terhadap abnormalitas spermatozoa.

\section{DAFTAR PUSTAKA}

Ardhani F., I.M.U. Raharja., B.M. Boangmanalu, dan D. Hanjoko. 2018. Karakteristik morfologik dan morfometrik spermatozoa ayam Nunukan. Jurnal Peternakan. 15(2):62-67.

Arief. Y.S. 2011. Stres dapat mengganggu proses spermatogenesis pada Mencit. Jurnal Ners. 6(2):169-174.

Ariyanti. R., N. Ulupi., T. Suryati, dan R.I. Arifantini. 2017. Performa produksi dan reproduksi ayam Sentul dengan konsentrasi IgY berbeda dalam serum darah. Jurnal Ilmu Produksi dan Teknologi Hasil Peternakan. 5(3):89-93.

Danang, D.R., N. Isnaini, dan P. Trisunuwati. 2012. Pengaruh lama simpan semen terhadap kualitas spermatozoa ayam kampung dalam pengencer Ringer's pada suhu $40^{\circ} \mathrm{C}$. Jurnal Ternak Tropika. 13(1):47-57.

Iskandar. S. 2012. Optimalisasi Protein dan Energi Ransum Untuk Meningkatkan Produksi Daging Ayam Lokal. Pengembangan Inovasi Pertanian. 5(2):96-107.

Johari. S., Y.S. Ondho., S. Wuwuh., Y.B. Henry,, dan Ratnaningrum. 2009. Karakteristik Dan Kualitas Semen Berbagai Galur Ayam Kedu. Prosiding Seminar Nasional Kebangkitan Peternakan - Semarang, 20 Mei 2009.

Nataamijaya, A.G. 2010. Pengembangan potensi ayam lokal untuk menunjang peningkatan kesejahteraan petani. Jurnal Litbang Pertanian. 29(4):131138.

Pusat Data dan Informasi Pertanian Kementrian Pertanian. 2016. Outlook Daging Ayam Komoditas Pertanian Subsektor Peternakan. Sekretariat Jendral - Kementrian Pertanian Republik Indonesia.

Saleh. D.M, dan A.Y. Isyanto. 2011. Pengaruh lama penyimpanan terhadap motilitas dan fertilitas spermatozoa ayam kate lokal. Jurnal Cakrawala Galuh. 1 (6):1-6.

Saleh. D.M. dan Sugiyatno. 2007. Pengaruh aras glycerol terhadap motilitas $\mathrm{dn}$ fertilitas spermatozoa ayam kampung yang dibekukan dengan nitrogen cair. Jurnal Animal Production. 9(1): 45-48.

Sutiyono., S. Riyadi, dan S. Kismiati. 2006. Fertilitas dan daya tetas telur dari ayam petelur hasil inseminasi buatan menggunakan semen ayam kampung yang diencerkan dengan bahan berbeda. Jurnal Indonesian Animal Agricutural. 31(1): 36-40.

Suyatno. 2003. Peningkatan produksi bibit ayam lurik melalui penerapan inseminasi buatan. Jurnal Dedikasi. 1(1):104-111.

Utami, I.A.P. 2009. Daya tahan spermatozoa ayam buras (peranakan Sentul) pada tiga macam pengencer. Jurnal Ganec Swara. 3(3): 39-42.

Zahri, A., A.O. Sudrajat, dan M. . Junior. 2018. Profil hormon FSH, LH dan Estradiol serta kadar glukosa darah Sidat, Anguilla Bicolor Bicolor (Mc Clelland, 1844) yang dirangsang hormon HCG, MT, E2 dan anti Dopamin. Jurnal Iktiologi Indonesia. 18(1):57-67. 